\title{
Implementasi Model Problem Based Learning Untuk Meningkatkan Keaktifan dan Hasil Belajar Peserta Didik Pada Pelajaran Administrasi Jaringan (Implementation of Problem Based Learning Model to Improve Student Activity and Learning Outcomes in Network Administration Lessons)
}

\author{
Wira Ardian Prasetyo ${ }^{1}$ \\ ${ }^{1}$ Guru pada SMKN 1 Banyudono Boyolali \\ Corresponding Author: Wira Ardian Prasetyo, E-mail: wapatosca07@gmail.com
}

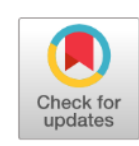

\begin{tabular}{l}
\hline ARTICLE INFO \\
\hline Received: 2021-11-07 \\
Accepted: $2021-11-15$ \\
Volume: 1 \\
Issue: 1 \\
DOI: \\
https://doi.org/10.53754/civilofficium.v1i1.224 \\
\hline KEYWORDS
\end{tabular}

Learning Activity, Learning Outcomes, Problem Based Learning Model.

\begin{abstract}
This study aimed to determine student activity and learning outcomes by implementing the Problem Based Learning (PBL) learning model. This research is classroom action research conducted in 2 cycles. The method of data collection was carried out through observation. Data analysis was carried out by comparing the test results in cycle 1 and cycle 2 with descriptive techniques after implementing the learning method using the Problem Based Learning model. Students' activeness can be seen from students who give full attention to the material, dare to ask the teacher, answer questions, and have opinions. In addition, students also collaborate in groups, work on questions, learn to use resources, and make group presentations. This study indicates that class XII students' learning outcomes and activities of SMK PUSTEK BSD, South Tangerang City, Banten Province, in the Basic Network Administration subject have increased.
\end{abstract}

\section{Pendahuluan}

Dewasa ini dan di masa mendatang warga dunia membutuhkan karakteristik sumber daya manusia yang memiliki kemampuan untuk dapat berpikir keras dan tinggi, memiliki kemampuan untuk memecahkan masalah serta dapat bekerja secara bersama-sama atau kolaboratif (Wagiran, 2007, p. 1). Karena itu untuk dapat melahirkan sumber daya sebagaimana yang dimaksud tersebut, negara harus segera memperbaiki kualitas pendidikannya (Syafaruddin, 2002, pp. 7-8). Kaitannya dengan agenda peningkatan kualitas pendidikan, negara akan mampu dan berhasil dalam agenda ini jika didukung dengan Sumber Daya Manusia yang berkualitas. Tidak hanya itu, perencanaan, pelaksanaan dan evaluasi Pendidikan pun juga harus dikelola dengan baik.

Namun sayangnya, jika kita tengok mengenai bagaimana realitas dan kondisi dari dunia pendidikan kita, ternyata bisa dibilang masih belum bisa memuaskan harapan masyarakat luas. Pandangan ini setidaknya bisa dilihat dari bukti nyata yang menunjukkan bahwa kualitas atau mutu lulusan dari peserta didik kita masih rendah. Bahkan, muncul pandangan-pandangan dari berbagai kalangan bahwa pendidikan di Indonesia lebih berorientasi pada proyek (Syafaruddin, 2002). Padahal sesungguhnya, menurut teori pendidikan yang dikembangkan oleh para pakar pendidikan, pendidikan yang diselenggarakan negara harus sesuai dengan kebutuhan dan harapan masyarakat luas.

Jika kita cermati mengenai hasil survei World Competitiveness Year Book yang dilakukan sejak tahun 1997 hingga tahun 2007 , pendidikan Indonesia menempati posisi ke 39 dari 49 negara yang disurvei. Sementara di tahun 1999 Indonesia menempati urutan 46 dari total 47 negara yang disurvei. Tidak jauh berbeda dari tahun-tahun sebelumnya, di tahun 2002 peringkat Pendidikan Indonesia di kancah global juga masih menempati posisi yang memprihatinkan, yakni Indonesia menempati peringkat 47 dari 49 negara yang disurvei. Sementara di tahun 2007, Indonesia juga masih menempati peringkat 53 dari 55 negara yang disurvei, begitu seterusnya hingga sekarang (Muhliz, 2009).

Fenomena ini barangkali menjadi sesuatu yang wajar saja, mengingat pendidikan di Indonesia yang memang penyelenggaraannya masih menitikberatkan pada kemampuan menghafal dan bukan menitikberatkan pada kemampuan 
analisis dan berpikir kritis. Kemudian, proses pembelajarannya yang juga masih belum memberi outcome yang memiliki dimensi knowledge sekaligus afektif dan psikomotorik. Selain itu, pendidikan kita masih membangun kelas yang titik fokusnya adalah guru (teacher centered learning) yang dijadikan sebagai sumber utama pengetahuan, sementara ceramah menjadi metode yang paling favorit (Burhanuddin, 2008).

Merespon mengenai fenomena hasil pembelajaran peserta didik yang kurang maksimal dan tingkat keaktifan peserta didik yang masih rendah tersebut muncul ide untuk melahirkan model dan metode pembelajaran yang sekiranya dapat merangsang peserta didik dapat lebih aktif dalam belajar. Salah satu metode yang dilahirkan dan ditawarkan ke permukaan adalah model atau metode pembelajaran berbasis masalah (Problem Based Learning). Bertolak dari latar belakang di atas, penelitian mengenai "Implementasi Model Problem Based Learning untuk Meningkatkan Keaktifan dan Hasil Belajar Peserta didik pada Pelajaran Administrasi Jaringan Dasar di SMK PUSTEK BSD Kota Tangerang Selatan Provinsi Banten" menjadi penting untuk dilakukan.

\section{Kajian Literatur}

Dalam perspektif (Hamalik, 2007, p. 57), belajar adalah aktivitas memodifikasi atau meneguhkan perilaku lewat pengalaman. Dari pengertian tersebut dapat dipahami bahwa belajar adalah sebuah proses, suatu aktivitas, dan tidak merupakan sesuatu bukan suatu hasil. Belajar merupakan proses peubah perilaku seseorang dengan cara berinteraksi dengan lingkungan. Belajar juga bisa dipahami sebagai sebuah proses mengubah perilaku individu yang relatif menetap sebagai hasil pengalaman dan interaksi dengan lingkungan dengan memakai proses kognitif (Muhibuddin, 2020).

Menurut Thorndike (Asri Budiningsih 2005, p. 21) belajar merupakan aktivitas yang menciptakan situasi dan kondisi di mana dapat terciptanya proses dialog antara rangsangan atau stimulus dan tanggapan atau respon. Stimulus bisa diartikan segala sesuatu yang memungkinkan bisa merangsang terjadinya aktivitas belajar. Sementara respon adalah tanggapan atau reaksi dari peserta didik saat belajar, baik respon yang berupa pikiran, perasaan, atau gerakan/tindakan.

Dari pengertian yang sudah disampaikan di atas, dapat ditarik benang merah bahwa hasil belajar berupa berubahnya perilaku itu dapat dilacak, sebab perubahan perilaku tersebut sifatnya kongkret dan tidak kongkret yang kesemuanya bisa diukur dan diamati. Kesimpulan lain mengenai belajar bisa dijelaskan bahwa belajar adalah kegiatan mengubah diri melalui membaca, menulis, berdiskusi, atau berdialog dengan pihak-pihak lain sehingga dapat mengubah seorang individu yang asalnya tidak tahu menjadi tahu, dari yang tidak bisa menjadi bisa, dan seterusnya. Belajar akan membawa suatu perubahan yang tidak hanya berkaitan dengan penambahan ilmu pengetahuan, tetapi juga berbentuk kecakapan, keterampilan, sikap, pengertian, harga diri, minat, watak, penyesuaian diri.

Terdapat beberapa prinsip belajar yang harus ditegakkan oleh guru sebagai fasilitator kegiatan pendidikan dan pembelajaran. Dalam perspektif (Slameto, 2010, p. 57) metode untuk menyusun prinsip- prinsip belajar adalah sebagai berikut, berdasarkan pada prasyarat yang dibutuhkan dalam belajar, sesuai hakikat belajar, Sesuai materi bahan yang harus dipelajari, dan Syarat keberhasilan belajar. Secara lebih rinci sesungguhnya tujuan dari pembelajaran adalah untuk, perubahan perilaku, mengubah kebiasaan, mengubah keterampilan, Menambah pengetahuan dalam berbagai bidang ilmu.

Hasil belajar yaitu sesuatu yang diperoleh atau yang dicapai oleh seseorang atau individu setelah seseorang tersebut melakukan kegiatan belajar secara serius. Hasil belajar seseorang memiliki wujud yakni berubahnya kompetensi-kompetensi seseorang dalam aspek kognitif, afektif dan psikomotorik. Pada umumnya, hasil belajar dipengaruhi oleh beberapa faktor(1) materi pelajaran, (2) lingkungan peserta didik, (3) sarana dan prasarana, (4) kondisi peserta didik, dan (5) proses pembelajaran. (Sudjana, 2008, p. 37) menjelaskan mengenai sejumlah hal yang berpengaruh terhadap hasil belajar. Sejumlah faktor tersebut yaitu faktor internal dan faktor eksternal. Faktor internal adalah faktor yang mempengaruhi hasil belajar individu yang datangnya dari dalam diri peserta didik tersebut. Sementara faktor eksternal adalah faktor yang berasal dari luar diri peserta didik atau sering disebut dengan factor lingkungan. Sedangkan dalam perspektif (Sanjaya, 2009) banyak faktor yang mempengaruhi hasil belajar. Misalnya, faktor guru atau pendidik, faktor peserta didik, fasilitas belajar atau sarana, media, dan faktor lingkungan Pendidikan yang melingkupi.

Para ahli memiliki pandangan yang berbeda-beda mengenai definisi dari Pembelajaran Berbasis Masalah. Namun perbedaannya hanya pada tataran redaksional saja dan menemukan kesamaan dalam tataran substansi. Pengertianpengertian tersebut misalnya, menurut Agus Suprijono, pembelajaran berbasis masalah yaitu model pembelajaran di mana peserta didik di setting untuk dapat menemukan sesuatu atau discovery learning. Karenanya, peserta didik didukung supaya dapat belajar secara aktif dengan konsep-konsep dan prinsip-prinsip (Supriyono, 2009, p. 68). Menurut Wina Sanjaya, pembelajaran berbasis masalah dapat diartikan sebagai srangkaian kegiatan pembelajaran di mana pembelajaran tersebut memberikan penekanan pada proses penyelesaian masalahyang dihadapi secara ilmiah (Sanjaya, 2008, p. 116). 
Dari sejumlah definisi yang sudah disampaikan para pakar tersebut dapat diambil kesimpulan bahwa pembelajaran berbasis masalah adalah model pendekatan pembelajaran yang memberikan penekanan khusus pada aktivitas peserta didik baik aktivitas berfikir, bersikap serta berkarya dalam menguraikan dan menyelesaikan segala masalah yang dihadapi. Karena itu tidak mengherankan jika model pembelajaran berbasis masalah (Problem Based Learning), disebut sebagai salah satu pembelajaran inovatif yang bisa menciptakan suasana pembelajaran yang aktif bagi peserta didik.

\section{Metodologi}

Penelitian ini termasuk ke dalam jenis Penelitian Tindakan Kelas (Classroom Action Research). Penelitian Tindakan Kelas (PTK) adalah sebuah penelitian tindakan yang dilaksanakan di kelas yang tujuannya adalah memperbaiki kualitas pembelajaran di sebuah kelas (Arikunto, 2006, p. 3). Pelaksanaan penelitian ini dilakukan di SMK PUSTEK BSD Kota Tangerang Selatan Provinsi Banten. Sementara waktu pelaksanaannya di Bulan Oktober 2021. Penelitian ini dilaksanakan ke dalam beberapa tahapan. Tahapan pertama dilakukan pada siklus satu dan kemudian dilanjutkan pada siklus kedua yang kemudian dilihat mengenai ada atau tidaknya peningkatan hasil belajar selaras dengan target yang diinginkan. Subjek dalam penelitian ini adalah peserta didik kelas peserta didik kelas XII SMK PUSTEK BSD Kota Tangerang Selatan Provinsi Banten. Rencana penelitian Tindakan kelas meliputi persiapan Kegiatan, perencanaan dan pelaksanaan tindakan, observasi, dan refleksi. Penelitian ini menggunakan teknik pengumpulan data antara lain observasi dan tes. Sementara penelitian tindakan kelas ini memakai instrumen tes dan non tes. Teknik analisis data yang dipakai pada penelitian ini yaitu analisis deskriptif. Sementara untuk mengukur prestasi belajar peserta didik memakai sistem nilai rata-rata kelas pada hasil evaluasi tiap siklus.

\section{Hasil dan pembahasan}

Penelitian tindakan kelas ini dilakukan sebanyak 2 siklus. Sementara di setiap siklus dilakukan pembelajaran sejumlah 2 pertemuan. Pada setiap minggunya setiap kelas memperoleh 2 jam pelajaran. Penelitian ini memakai waktu dua jam pelajaran sebab dengan alokasi waktu 2X45 menit tersebut lebih cukup untuk meneliti sejak dari perencanaan, tindakan, pengamatan dan refleksi. Sedangkan materi pokok yang dipakai adalah design Jaringan Lokal LAN, perawatan jaringan lokal LAN, permasalahan jaringan lokal LAN. Sementara pendekatannya menggunakan saintifik, TPACK, menggunakan model Problem Based Learning, dan metode pembelajaran memakai metode ceramah, tanya jawab, penugasan, dan diskusi kelompok.

\subsubsection{Hasil Penelitian Siklus I (Pertemuan 1 dan 2)}

Data mengenai hasil belajar peserta didik sebelum tindakan (pretest) siklus I dipakai untuk mengetahui nilai peserta didik sebelum dilaksanakan tindakan siklus 1 dan posttest I untuk mengukur sejauh mana keberhasilan sesudah dilaksanakan tindakan siklus I. Sedangkan hasilnya bisa dilihat pada tabel 8 di bawah ini:

Tabel 1. Hasil Pre-test dan Post-test Peserta didik Siklus I

\begin{tabular}{cccc}
\hline No. & NAMA & NILAI & POST TEST I \\
\hline 1. & Annisa Cikal Ardini & 100 \\
2. & Bela Annisa Putri & 85 & 90 \\
3. & Deas Widiya & 85 & 95 \\
4. & Giska Putri Auliya & 75 & 95 \\
5. & Jelita & 70 & 85 \\
6. & Lita Veliana & 45 & 80 \\
7. & M. Dzaudan & 55 & 95 \\
8. & M. Rafi Naufal & 45 & 80 \\
9. & M. Azmi Fauzan & 65 & 90 \\
10. & Siti Ade Nur Savira & 80 & 95 \\
\hline
\end{tabular}



11.
Ubaydillah
60
95
12.
Yafi Rizki Darmawansyah
60
95

Dari tabel di atas terlihat bahwa hasil belajar peserta didik sebelum tindakan siklus I menunjukkan bahwa nilai pre-test I adalah minimum 45 dan nilai tertinggi 85. Dan hasil belajar siklus I setelah dilaksanakan tindakan menunjukkan bahwasan nilai post-test I minimum 80 dan nilai tertinggi 100. Nilai rata-rata hasil belajar peserta didik siklus I sebesar 92 didapatkan dari rumus nilai rata-rata.

Dari data di atas bisa ditentukan frekuensi dan persentase hasil belajar peserta didik siklus I dibagi menjadi 5 kategori yang bisa dilihat pada Tabel 9 di bawah ini ini.

Tabel 2. Frekuensi dan Persentase Kategori Hasil Belajar Peserta didik Siklus I

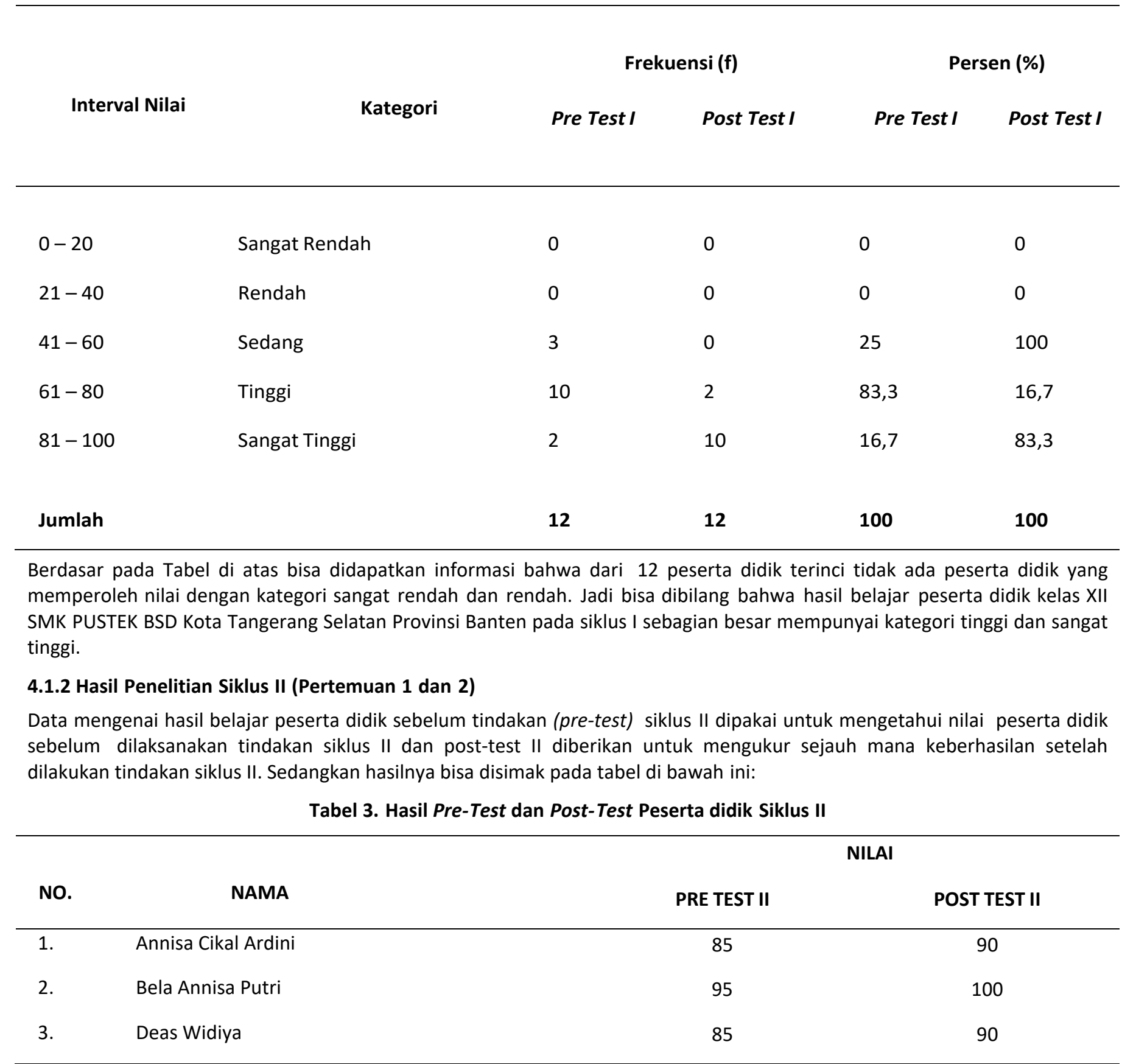




$\begin{array}{llll}\text { 4. } & \text { Giska Putri Auliya } & 100 & 100 \\ \text { 5. } & \text { Jelita } & 95 & 90 \\ 6 . & \text { Lita Veliana } & 90 & 90 \\ \text { 7. } & \text { M. Dzaudan } & 90 & 100 \\ 8 . & \text { M. Rafi Naufal } & 90 & 85 \\ 9 . & \text { M. Azmi Fauzan } & 75 & 100 \\ 10 . & \text { Siti Ade Nur Savira } & 80 & 95 \\ 11 . & \text { Ubaydillah } & 95 & \mathbf{1 1 2 0} \\ 12 . & \text { Yafi Rizki Darmawansyah } & 95 & \mathbf{9 3}\end{array}$

Berdasar pada tabel di atas bisa didapatkan hasil belajar peserta didik sebelum tindakan siklus II menunjukkan bahwa nilai pre-test adalah minimum 75 dan nilai tertinggi 100. Dan hasil belajar setelah tindakan menunjukkan bahwa nilai post-test minimum 85 dan nilai tertinggi 100. Nilai rata-rata hasil belajar peserta didik siklus II sebesar 93 didapatkan dari rumus nilai rata-rata. Dari data tabel 10 tersebut bisa ditentukan frekuensi dan persentase hasil belajar peserta didik siklus II dibagi menjadi 5 kategori yang bisa dilihat pada Tabel di bawah ini.

Tabel 4. Frekuensi dan Persentase Kategori Hasil Belajar Peserta didik Pre test Siklus II

Frekuensi (f)

Interval

Nilai

Kategori

Pre-Test II

Post-Test II

Pre-Test II

Persen (\%)

\begin{tabular}{|c|c|c|c|c|c|}
\hline $0-20$ & Sangat Rendah & 0 & 0 & 0 & 0 \\
\hline $21-40$ & Rendah & 0 & 0 & 0 & 0 \\
\hline $41-60$ & Sedang & 0 & 0 & 0 & 0 \\
\hline $61-80$ & Tinggi & 2 & 0 & 16,7 & 0 \\
\hline Jumlah & & 30 & 30 & 100 & 100 \\
\hline
\end{tabular}

Berdasar pada Tabel 11 di atas, didapatkan informasi bahwa dari 12 peserta didik terperinci tidak ada peserta didik yang memiliki nilai dengan kategori sangat rendah dan rendah. Jadi bisa dibilang bahwa hasil belajar peserta didik kelas XII SMK PUSTEK BSD Kota Tangerang Selatan Provinsi Banten pada siklus II sebagian besar memperoleh kategori tinggi dan sangat tinggi.

\subsubsection{Analisis Aktivitas Peserta didik}

Analisis aktivitas peserta didik dalam pembelajaran Mata Pelajaran Komputer dan Jaringan Dasar dengan materi Instalasi Jaringan Lokal Area Network (LAN) dan Sub Materi Mengevaluasi dan Mengelola jaringan lokal (LAN) memakai pendekatan 
Problem Based Learning dianalisis secara deskriptif persentase. Persentase keaktifan peserta didik yang meningkat dari pertemuan 1 sampai pertemuan 4 adalah indikator keberhasilan metode tersebut. Peningkatan keaktifan peserta didik dapat dilihat pada tabel 12 berikut ini:

Tabel 5 Distribusi Persentase Keaktifan Peserta didik Tiap Pertemuan

\begin{tabular}{|c|c|c|c|}
\hline No. & Aktivitas & Siklus I & Siklus II \\
\hline 1. & Listening activities & $86 \%$ & $88 \%$ \\
\hline 2. & Oral activities & $45 \%$ & $61 \%$ \\
\hline 3. & Visual activities & $35 \%$ & $78 \%$ \\
\hline 4. & Writing activities & $65 \%$ & $73 \%$ \\
\hline 5. & Drawing activities & $53 \%$ & $21 \%$ \\
\hline 6. & Motor activities & $39 \%$ & $69 \%$ \\
\hline
\end{tabular}

Dari data yang disajikan dalam tabel 12 terlihat bahwa keaktifan peserta didik pada setiap kategori mengalami peningkatan. Bertolak dari data tabel di atas bisa ditentukan grafik keaktifan peserta didik seperti di bawah ini:

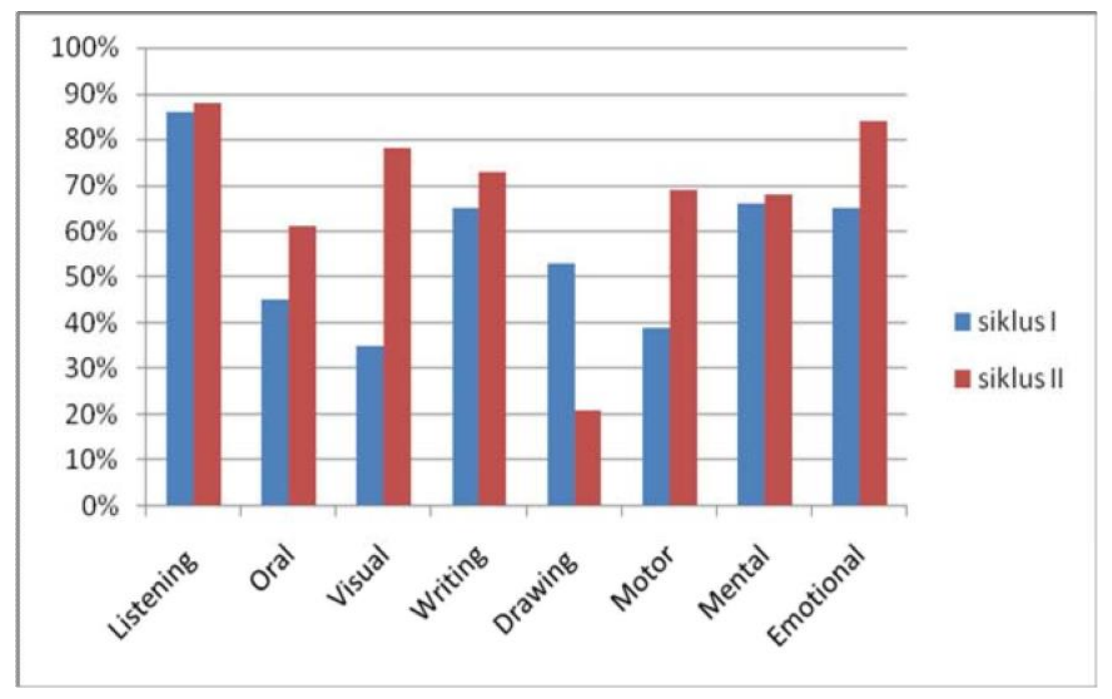

Gambar 2. Grafik Persentase Keaktifan Belajar Peserta didik Pada Siklus I dan Siklus II.

Bertolak pada deskripsi penelitian dan hasil penelitian yang telah disajikan sebelumnya, bisa dibilang bahwa rata-rata hasil belajar peserta didik kelas XII SMK PUSTEK BSD Kota Tangerang Selatan Provinsi Banten dari siklus I ke siklus II meningkat rata-rata hasil belajarnya. Peningkatan rata-rata nilai ini lantaran peserta didik yang mudah menyerap materi dengan metode belajar PBL. Sebab PBL bisa memberikan rangsangan kepada terbukanya pikiran atau menjadikan peserta didik menjadi open minded dan memberi dorongan kepada peserta didik supaya dapat belajar lebih kritis dan aktif.

Metode PBL juga memberi tantangan tersendiri bagi peserta didik yang mengantarkan mereka menjadi pribadi-pribadi yang menemukan pengetahuan baru untuk dirinya sendiri sehingga dari situ mereka akan menemukan kepuasan yang lebih. Berdasar pada hasil observasi kegiatan peserta didik didapatkan informasi bahwa terdapat peningkatan aktivitas listening, oral, emotional, visual, writing, motor, mental, dan visual. 
Hal ini menunjukkan bahwa peserta didik mulai memberikan responnya yang positif terhadap materi yang disimak. Diantara respon-respon yang ditunjukkan peserta didik adalah memberi perhatian penuh pada pelajaran yang disampaikan, berani berpendapat, berani menanyakan segala bentuk materi yang belum dipahami. Dengan memakai metode belajar PBL peserta didik menjadi lebih mudah memahami materi sebab model belajar mereka langsung mengaji segala bentuk permasalahan yang diambil dari kehidupan nyata yang diambil dari sekitar kita. Dari pembelajaran model PBL tersebut peserta didik menjadi memperoleh pengetahuan sekaligus metode mengimplementasikannya.

Melihat hasil tersebut, model Problem Based Learning bisa dibilang mampu membantu dalam hal peningkatan hasil belajar peserta didik dalam pembelajaran pembelajaran Mata Pelajaran Komputer dan Jaringan Dasar di SMK PUSTEK BSD Kota Tangerang Selatan Provinsi Banten.

\section{Simpulan}

Hasil dari Penelitian Tindakan Kelas menggunakan model Problem Based Learning adalah, pertama, hasil penelitian aktivitas peserta didik diperoleh informasi bahwa adanya peningkatan peserta didik kelas XII SMK PUSTEK BSD Kota Tangerang Selatan Provinsi Banten setelah diterapkannya metode belajar dengan menggunakan model PBL. Keaktifan peserta didik dapat dilihat dari aspek peserta didik yang memberi perhatian penuh terhadap materi, peserta didik berani bertanya kepada guru, peserta didik berani menjawab pertanyaan, peserta didik berani berpendapat, kerjasama dalam kelompok, mengerjakan soal, belajar menggunakan sumber, dan presentasi kelompok dari siklus I sampai II sebagian besar aspek mengalami peningkatan. Kedua, penerapan model Problem Based Learning dapat membantu meningkatkan hasil belajar peserta didik kelas XII SMK PUSTEK BSD Kota Tangerang Selatan Provinsi Banten.

\section{Daftar Pustaka}

[1] Arikunto, S. (2006). Prosedur Penelitian Suatu Pendekatan Praktik. Rineka Cipta.

[2] Hamalik, O. (2007). Dasar-Dasar Pengembangan Kurikulum. Remaja Rosdakarya.

[3] Muhibuddin, J. (2020). Perkembangan Jiwa Beragama Pada Masa Anak-Anak. In Al-Ikhtibar: Jurnal Ilmu Pendidikan (Vol. 7, Issue 2, pp. 801-808). IAIN Langsa. https://doi.org/10.32505/ikhtibar.v7i2.617

[4] Muhliz. (2009). Urutan Kualitas Pendidikan Indonesia Di Mata Dunia Dari 1997- 2007.

[5] Sanjaya, W. (2008). Strategi Pembelajaran Berorientasi Standar Proses Pendidikan. Jakarta: Kencana Prenada Media Group. Kencana.

[6] Sanjaya, W. (2009). Kurikulum dan Pembelajaran: Teori dan Praktik Pengembangan, KTSP Jakarta. In Kencana Prenada Media Group.

[7] Slameto. (2010). Belajar dan Faktor-Faktor yang Mempengaruhi. Rineka Cipta.

[8] Sudjana, N. (2008). Penilaian hasil proses belajar mengajar. Remaja Rosdakarya.

[9] Supriyono, A. (2009). Cooperatif Learning. Pustaka Pelajar.

[10] Syafaruddin. (2002). Manajemen Penelitian Tindakan Kelas. Grasindo.

[11] Wagiran. (2007). Peningkatan Keaktifan Mahapeserta didik dan Reduksi Miskonsepsi Melalui Pendekatan Problem Based Learning. Jurnal Kependidikan.

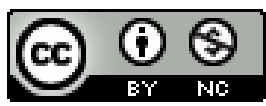

(C) 2021 by the authors. Submitted for possible open access publication under the terms and conditions of the Creative Commons Attribution-NonCommercial 4.0 International License (CC BY NC) license (https://creativecommons.org/licenses/by-nc/4.0/). 